\title{
INTERVIEW: DR. ANDREA O'REILLY AND THE MOTHERHOOD PERSPECTIVE
}

Dr. Andrea O'Reilly is Full Professor in the School of Gender, Sexuality and Women's Studies at York University, founder/editor-in-chief of the Journal of the Motherhood Initiative and publisher of Demeter Press. With more than two published books, her work involves especially the fight for gender equity and women's rights.

Among the works edited or co-edited by Dr O'Reilly are Maternal Theory: Essential Readings (2007), The Encyclopedia on Motherhood (2010), The Routledge Companion to Motherhood (2019), Feminist Parenting: Perspectives from Africa and Beyond (2020), Mothers, Mothering and COVID-19: Dispatches from a Pandemic (2020). She is also author of Tony Morrison and Motherhood: A Politics of the Heart (2004); Rocking the Cradle: Thoughts on Motherhood, Feminism and the Possibility of Empowered Mothering (2006), and Matricentric Feminism: Theory Activism and Practice (2016).

Andrea is twice the recipient of York University's "Professor of the Year Award" for teaching excellence. In 2019 she was awarded the Status of Women and Equity Award of Distinction from OCUFA (Ontario Confederation of University Faculty Associations) as public recognition of her activism for the improvement of the life and working conditions of female students and researchers, native and racialized women, the LGBTQIA+ populations, people with disabilities or belonging to other historically marginalized groups. On this occasion, Andrea stood out not only as a leading researcher in her field, but also as an activist committed to women's rights causes, locally, nationally and globally.

She was the founder and director of MIRCI (The Motherhood Initiative for Research and Community Involvement), from 1998 to 2019, establishing a global community of researchers and activists including more than 400 universities. She founded and is the director of the Journal of Motherhood Initiative and Demeter Press, the first feminist publishing house specialized in mothering, motherhood, reproduction, family and sexuality. Andrea is the mother of two adult daughters and one adult son.E-mail: aoreilly@yorku.ca

Dr O'Reilly was interviewed remotely on May 1oth 2021 by Dr Elizabeth Souto Maior and Dr Maria Collier de Mendonça in Brazil while Andrea was in her country home on the shores of Peter Lake, Canada.

Maria Elizabeth P. Souto Maior Mendes

Full Professor at Universidade Federal da Paraíba (UFPB), Brazil. E-mail: mepsmm@academico.ufpb. br

Maria Collier de Mendonça

Full Professor at Universidade Federal de Pernambuco (UFPE), Brazil. E-mail: maria.cmendonca@ ufpe.br 
E.S.M.: It is my greatest honour and pleasure to interview $\mathrm{Dr}$ Andrea O'Reilly for this special issue of Ártemis. I would like to start from the beginning of your academic career. We all know how challenging it can be to discover a research theme which truly mobilizes a scholar's passion. How did you come across mothering and motherhood as your research theme?

O'Reilly: A slogan of feminism has always been "The personal is political" and that certainly was the case for me, coming to the topic of mothering and motherhood. I became pregnant at 22 and was a mother at 23, certainly not planned. I had the baby in the final year of my Honours BA and had two more children in the early years of my $\mathrm{PhD}$, also not planned. The first pregnancy and birth was a moment of reckoning and awakening for me. I was a women's studies major at the time-1981 to 1984and I was taking every imaginable course, from history, health, literature, and film. However, motherhood was simply not a topic of discussion in the courses: women and health, work, sexuality, and domestic violence were the topics of discussion in these classes. As a non-mother at the time I didn't notice the absence of motherhood as a topic in my women's studies courses. The few times it was talked about, it was in a negative context such as the liberal feminist perspective that positions "motherhood as a patriarchal trap" with sentiments like "motherhood opresses you," and "don't be a mother." When I became a mother, I had a brief falling out with feminism because some of my colleagues looked at me suspiciously when I became a mother. Even though I was active in various movements as an undergrad student such as the peace movement, the anti cruise missile movement, and others, a lot of my colleagues/ comrades looked at me as if I had sold out and gone over to the other side. After all, why would a good feminist like me become a mother?

E.S.M.: So one could say your choice of research topic was tied to very personal reasons. How did you feel at that point?

O'Reilly: I always cite Toni Morrison when she says "I wrote the books I needed to read." Well, for me, I started the research that I needed, that wasn't there for me when I became a mother. I was the only mother in my graduate program and felt so otherized, so alone, and so unsupported. So it was a personal experience that galvanized and motivated me to take up mothering as an area of study.

E.S.M.: Could you tell us a little bit about the process of writing Toni Morrison and Motherhood: a Politics of the Heart?

O'Reilly: It was in fact my dissertation. After I completed my $\mathrm{PhD}$ in 1996, I developed my dissertation into a book. Discovering Toni Morrison was again one of those life-changing moments. In the early years of my $\mathrm{PhD}$, I was teaching Song of Solomon in a course as a Teaching Assistant, but had not read any of Morrison's 
other novels. In 1987/88 I took an African American literature course and we were reading Morrison in this class. My professor pulled me aside and said, "Beloved has just come out and you really need to read the novel because I know you are interested in the topic of mothering." I stayed up the entire night and read it, even though I had a thirteen-month-old and a three-year-old that were soon to be awake. I remember thinking “That's it!" So I went to my professor shortly thereafter and said "I'm doing my thesis on Morrison." At that time, my thesis was on the rise of the novel in eighteenth century British literature. So let's just say it was a bit of a change of focus. Though I believed my initial topic was important, I knew I had to do Morrison because she was saying something that nobody else was saying about mothering at the time: something radical, political, revolutionary, paradigm shifting. And what she was saying went beyond her own writing and black mothers' experiences of mothering. Morrison was arguing that mothering can be a site of empowerment, social activism, a place of power for women. She put mothering in a theoretical and political context that I had not seen a novelist do before. So that's why I was compelled to read all of her novels and do a dissertation on her. And I named my book 'A Politics of the Heart' because I think Morrison sees mothering as highly political; not simply the natural intuitive calling of women as assumed in normative motherhood.

M.C.M.: When we think about literature and the development of your discussions on mothering, is it still relevant to your present research?

O'Reilly: Definitely. Although I have a PhD in English, for the last twenty years I've strayed from that and done more qualitative and theoretical research. I have now returned to my passion for and training in literature and I'm currently writing articles which will become a monograph on mothering in post 2010 women's fiction and memoir. It is quite astounding how much has been published on the topic of mothering in women's fiction over the last five to ten years. When I became a mother there were few novels about mothering. Almost every other book that's coming out now in the genres of speculative fiction, psychological thrillers, crime fiction, and memoir has mothering as central to their plots and themes. My current research is close textual readings of mothering in post 2010 woman's fiction to explore how contemporary mother authors are using literature to critique normative motherhood.

E.S.M.: Has your present research included more black or white female authors? Do you feel there is a balance between them?

O'Reilly: It's a little bit of both and I'm hoping to do more. I have an article in this journal that explores the unexamined whiteness of the motherhood memoir ${ }^{1}$

1 We understand 'motherhood memoir' is being used in this context by the interviewee as a kind of autobiographical writing by femaleauthors who narrate her maternal experiences and their effects in her life. 
to consider how normative motherhood is enacted and how it may be resisted in the motherhood memoir genre. The article then consider how Nefertiti Austin's best selling motherhood memoir-Motherhood So White: A Memoir of Race, Gender, and Parenting in America (2019) — in its black maternal standpoint and thematics of motherwork, other/communal mothering, mothering as social activism subverts the presumptions, priorities, and practices of the normative motherhood memoir to radically redefine and reform the genre and deliver a counter black maternal narrative of empowerment and resistance. In a recently completed article I consider how Asian American novelist Celeste $\mathrm{Ng}$ uncovers the intergenerational effects of normative motherhood; how the mothers' experiences in and with normative motherhood are transmitted and transferred to the daughter and gives rise to the disempowerment of the daughter and estrangement between mother and daughter. I also plan to do a chapter or two specifically on black woman's literature post 2010. I've read more books this year during my sabbatical in the pandemic lockdown than I ever have before.

M.C.M.: In 2006 you coined the term 'motherhood studies', and I quote "to acknowledge and demarcate this new scholarship on motherhood as a legitimate and distinctive discipline, grounded on maternal theory developed by Rich, Ruddick, Collins, among others.”. In 2021, after launching the second edition of Matricentric Feminism: Theory, Activism, and Practice, you are launching the second edition of the collection Maternal Theory: Essential Readings, with sixty chapters written by very relevant authors in this field. We would like to look back at the last fifteen years: to your mind what has evolved regarding motherhood studies in the academy?

O'Reilly: When I did the first collection Maternal Theory: Essential Readings, in twothousand-seven, I did so for my Mothering and Motherhood course that I've taught at York University in Toronto, Canada since nineteen-ninety. It's a second-year course with a hundred to a hundred and fifty students with a lecture format and tutorials. I didn't have a course text back then and used those course kits. I thought, "Enough is enough. I'm going to create a book for my course!" So that's when the first edition came out that included the "must-read" maternal theorists. I also asked a few people to collaborate. For example, Kim Anderson did a chapter on Indigenous Mothering. Ariel Gore did another chapter on hip, i.e., young mothers. However, three or four years ago I started feeling that the first edition had become dated because so much more has been said on mothering since 2007. In the 2 nd editon we have new compelling themes that had not been fully explored in 2007: chapters on non-binary parenting, trans parenting, queer mothering, the motherline, the motherhood memoir, and the digital maternal. We also have a chapter on disabled mothers, which looks very different in 2021 than the chapter I had in 2007. So some of the topics are absolutely brand new, others are familiar topics, but with really relevant updates.

The term was translated henceforth as 'escrita do gênero memorialista sobre a/ que aborda a maternidade'. 
E.S.M.: What has happened to motherhood studies in the past thirty five years? What themes do you think will have to be incorporated in the future?

O'Reilly: It's been forty-five years since Rich's classic book Of Woman Born was published and a lot has happened in four decades. I suspect ten years from now we'll need a third edition because there will always be other new theories and issues. For example, in the 2 nd edition we have a chapter on pandemic mothering as a theoretical concept. The first edition was used in countless courses and I hope I haven't removed chapters that people wanted in the second one. I'm very happy with the results, the chapters coming in are stunning, breathtaking. It is really amazing that this much has happened in a really short period of time.

M.C.M.: As for the latest topics in the field of motherhood studies, what can we expect in this new publication?

O'Reilly: I think pandemic mothering is not just a topic but is a theoretical concept as it has shown how care labour is gendered. For the 2nd edition of Maternal Theory, Fiona Green and I revised our introduction to our book Mothers, Mothering, and Covid-19: Dispatches from a Pandemic. In the 2nd edition we also have two chapters on literature, one on the motherhood memoir and a great chapter on maternal narratology picking up Hirsch's notion of the maternal plot, but bringing it to a new place in 2021. Other chapters explore recent theoretical concepts such as Feminist Fathering, Matricentric Feminsim, Maternal Regret, Maternal Ambivalence, Reproductive Justice, and the Migrant Maternal. Even though the contributors are largely North American, we have Australians, and several from Europe and the U.K. But maternal theory still needs to become more global.

M.C.M.: This idea of incorporating global issues brings us to our next question: how can we move forward on this motherhood scholarship journey?

O'Reilly: I was on a panel ten years ago, at the National Women's Studies Association annual conference, and the topic was how to make motherhood studies global. We're making slow inroads on that, but it is still very much a challenge. I think in terms of Indigenous issues certainly Demeter Press has published a great deal along with Chicana and Black maternal issues. However, our press still needs to become more global. Women's studies had the same trajectory: it took women's studies a couple of decades to become global. Even though it started in the late 196os, it wasn't really until the nineties that you could say women's studies had a more global perspective. So I'm hoping that with time and work motherhood studies and maternal theory will likewise grow to become a more global discipline. 
E.S.M.: Whenever we think about Latin America, there is still so much to be researched [on motherhood]. What exactly would your suggestions be for researchers to develop this field here in Brazil and in Latin America even further?

O'Reilly: That is not an easy question to answer because I'm hearing that even in the North American context motherhood studies is becoming even more vulnerable, and even more marginalized than ten years ago. I think things are getting worse in terms of undertaking motherhood studies. It's increasingly hard with the rise of gender studies, with the rise of more trans and non-binary studies, because motherhood is increasingly being seen as essentialist and reactionary. Every time I write or say "motherhood is the most radicalizing thing that ever happened to me" it's not seen that way. So, I think things are tough right now, particularly because of the pandemic with departmental cut-backs and closures.

M.C.M.: Considering the global difficulties we have been facing in Motherhood Studies, would you say the field might grow or not?

O'Reilly: How do you create a new field, or grow a field, in a disaster zone? I have lots of graduate students who are very nervous. They do motherhood studies, but they know in the job market they can't market themselves as a motherhood studies scholar. There are no jobs for them in motherhood studies as it still does not exist as a discipline.

E.S.M: So, in a way, it takes courage to embark on this journey. Scholars need to connect the theme of motherhood to other fields so as not to seem they are doing maternal studies in a vacuum, right?

O'Reilly: Yes, exactly. So what scholars often do is they disguise or marginize the motherhood focus of their research; if they are doing research on refugee mothers they say they are refugee studies scholars, so as to get a job.

M.C.M.: Do we still have more mothers than non-mothers and more women than men in the motherhood studies field?

O'Reilly: Do you have to be a mother to do motherhood studies? First of all, the answer is obviously no. Some great motherhood scholars are not mothers. But in my experience, most people doing motherhood studies are mothers or identify as mothers. Though I think in certain fields, such as communications and social media studies, it is changing and you're seeing more men, and more non-mothers doing motherhood research. But my experience is that most people are drawn to the topic of motherhood because they are mothers. Even though that sounds essentialist, I think most of what we do or what we are drawn to is because of what happens in 
our life. So, people might study class because they grew up working class, or they might study disability because they or someone they know is disabled. We're often drawn to our areas of research because of something in us. But when this is the case with mothers, we're dismissed as essentialists. I think good scholarship is driven by passion and commitment. Mother scholars are often driven by a necessary lived interest in the subject matter. This is a matter of survival; it isn't just academic.

M.C.M.: It is important to find a field and an impactful topic that has social implications.

O'Reilly: Yes, absolutely. With Demeter Press and MIRCI (Motherhood Initiative for Research and Community Involvement) and its journal we have an absolute commitment to this. At our conferences, we had many activists, community organizers, artists, students, and mothers. We wanted people to meet as equals, and to bring their own expertise. Our mandate was accessibility, and transparency. Having said that, some Demeter books are heavy and theoretical, and maybe they're not the ones that non-academic activists are going to pick up to read. But in our journal, we have a mandate of accessibility. I've turned back good articles that were too dense, too specialized, too jargonistic, too heavy. I said "if you can unpack this a bit, then we'd love to publish it." I always wonder why so much theory is deliberately obtuse: what is the point of writing if your mandate is to confuse people. You can be really smart and groundbreaking and still speak in an accessible language. But there's this belief that the harder you are to understand, the more brilliant you must be. We challenge this at Demeter and JMI, and at our conferences. We want to get motherhood research into the hands and minds of everyday people, and stop talking to each other in the ivory tower.

E.S.M.: How about this experience of your academic project regarding motherhood and the COVID-19 pandemic? Can you elaborate a little bit on how the pandemic has taken a toll on women across the world, especially academics?

O'Reilly: Of course. The backstory to this project is that in the early months of the pandemic I was watching the news like everybody else and noticed that few people were talking about mothers and all they were doing to keep families functioning. Everybody was thanking doctors, nurses, sanitation workers, bus and truck drivers. This, of course, is perfectly fine. These people were taking care of us, getting food to our tables, making sure we're safe and cared for. But nobody was thanking mothers which surprised and angered me. My Facebook feed was full of stories of mothers struggling, doing the impossible, keeping families functioning as they transitioned to working from home, taking up homeschooling, remote learning, and yet there was this deafening silence on all of this in the media. So, in April 2020, I created the hashtag \#mothersarefrontlineworkers, and the "Mothers and COVID 19" Facebook 
group. I then decided to do a book on mothers and Covid-19 and contacted Fiona Green and she agreed to edit the book with me. We sent out a call for papers and received more abstracts for this book than we have ever received for a Demeter collection. And many other mothers contacted us and said "I would love to submit an abstract but the topic of the book, i.e., mothering, is preventing me from doing so". We also created a special double journal issue on academic motherhood and COVID-19, which was published in December 2020, and is available online, open access to anyone in the world. And we published the book Mothers, Mothering, and Covid-19: Dispatches from a Pandemic in March 2021, 540 pages, 45 chapters, and 70 contributors from a dozen countries. We had so many good submissions and even though we published this massive book and a double journal issue we still had to turn back a lot of good ones.

Throughout the pandemic we often say while we may be in the same storm, we are not in the same boat. The pandemic has most negatively impacted women, particularly women who are mothers. Women are the ones largely doing the necessary eldercare, and many women have lost their jobs because most of the pandemic job losses have been in traditionally women's occupations - service, tourism, and retail. Economists, not feminists, are calling this current recession a "she recession" as it has affected women more than men. The job losses are staggering. Part of the reason for this is that women's jobs have been furloughed. Another reason is that women have been pushed out of the labour force because they cannot do four jobs at once. They can't do paid work in the home, the second shift of housework, the third shift of emotional labor of caring for families, and the fourth shift, which is homeschooling. It's impossible for anyone to do four jobs at once, it does not matter how organized you are, or how much money you make. And the resources and support networks that once supported mothers are all gone. Childcare centers are closing in Canada. They're going bankrupt and closing permanently because there aren't children in them. So, this is a crisis. When these women finally return to work, there might not be childcare centers. It's unequivocal that it is women as mothers who have been most negatively impacted by the pandemic. The statistics are there. And it's not just feminists, it's economists saying this. Women are doing more work in the home, at the expense of their mental health, leisure, and their careers. They are stepping back, cutting their working hours, they're going down to three working days if their boss will let them; otherwise, they're quitting. In academia women are submitting fewer articles, receiving less grants. For the small survey I did in June 2020, which consisted simply of asking mothers to send their thoughts over email I had several academic mothers say, "I couldn't get that grant done," or "I'm not going to get my monograph finished and therefore I am not going to get tenure." Many grad students are taking leaves, others are way behind. The pandemic is taking a huge hit on academic women's productivity, and the damage is going to be felt many years to 
come. It has always been very dire and grim for mothers in academia and I think it's only going to get worse because of the pandemic.

M.C.M.: What has been your assessment of universities meeting maternal needs? Would you say there was progress in the thirty-one years that you have taught at York University? Do you think there were relevant changes taking place inside or outside of Canadian universities in order to meet maternal needs?

O'Reilly: I think it's variable and it depends on the university. In Canada, other than our national maternity leave, universities have their own policies and procedures. Some universities have good policies, others don't. Canada does have a maternity leave of 12 months, which can be extended to 18 months, where you receive around $50 \%$ of your salary. The question is whether women use all of their leave, and often they don't because an extended maternity could be career suicide. As a consequence, a lot of mothers are back to work before what is legally allowed. At York, we do have to stop the clock on tenure. Graduate students also now have maternity leave. When I had my children back in the late 1980s, there was no maternity leave. It was actually my case that gave rise to the maternity leave provision at York. What I experienced as a mother in graduate school was so horrific and so blatantly discriminatory, a committee was created and a petition for graduate student maternity leave went to the Senate. In 1990 they finally implemented maternity leave for graduate students. But as recently as the late 1980 os there was no maternity leave for graduate students at York, no extra time given. Now, graduate students have an additional year and I believe now TA's (Teaching Assistants) get four or five months. So, things have most definitely improved at York in terms of policy, but I'm still seeing a lot of mother grad students who are struggling, not having finished their dissertations because their children get sick, or is there simply too much to do as a mother and a student. There are some things policies can't address, right?

E.S.M.: I would like to know if you feel there are still prevalent patriarchal and neoliberal values inside the academia that prevent a more inclusive and decolonial perspective on motherhood studies.

O'Reilly: Emphatically yes. And I would say it's getting worse. The more I think about this, the more I think it's just really disheartening. We have a chapter in Maternal Theory on mothering and neoliberalism. Some feminists have embraced the neoliberal paradigm and choice feminism believing you can make it if you can talk and walk like a man and be that resilient, reliant, self-sufficient subject. And you know what? That may be true for some women. But what about the rest of us who can't be that person? Whether it's because of health, race, or because you're a mother. Of course, there's pushback, and a lot of leftist scholars and more activist feminists are challenging choice feminism, but its neoliberal backing is very much alive and 
well. It's patriarchy with a new face, one that's harder to recognize because it looks nice and friendly. It's like "oh, well, you can do whatever you want, and just work hard." In the end it's simply a new form of control and one that is more dangerous, more insidious. Virginia Woolf once talked about not being physically allowed into a library. If that happens, you can identify your enemies, you can see what the problem is, and you can start a petition, and you protest. Today, they may not be blocking you from the library, but it's in your head that you don't deserve to be in that library. Or you can't get into the library because there isn't a ramp. Do you see what I'm saying? Because the enemy is more insidious, invisible, and internalized now, I think it's harder to thrash the enemy out. We can't see it. Some people are just saying to mothers, "get it together, we live in an equal world. It's just your problem that you can't manage, right?" Before, at least we knew that women were not allowed to do certain things because laws prevented them from doing them. But now if women are failing, if they can't be that supermom, it's their fault. We have a great chapter in the 2nd edition of Maternal Theory on the juggling mother, which is such a fascinating new theoretical concept: the juggling mother who is so neoliberal and perfect because she's got it together. And it's all over the media now, these images of mothers who might be a bit frazzled but they are still holding it all together. So, I do think we have got a harder battle ahead of us. While the old patriarchy was certainly hard it was easier to recognize and fight against.

E.S.M.: So we are definitely waging a war against an invisible enemy, one without a face?

O'Reilly: There often isn't a face because we have internalized all the messages so that mothers are blaming themselves for their failures, or their inability to be who patriarchy is telling them they can be if they only got themselves together. But having said that, I think there's also more resistance now and mothers are mobilizing. Mothers are central to the current Black Lives Matter movement with their on the ground activism for Black children who've been murdered by the police. Maternal activism ebbs and flows but it will never go away. Mothers have always been a central part of social change, and they will continue to be so.

E.S.M.: Yeah. The African proverb says that "it takes a village to raise a child". In your opinion, how has the motherhood scholars' village been built and sustained?

O'Reilly: For me, personally, it is my community and I couldn't have done the work I do without it. We need this support to provide validation and recognition. I do think that our current community of mother scholars created through our shared research and activism is a vibrant and supportive community. We know each other, we've read each other's work, we've met at conferences. People email each other and say, "I'm doing this work, could you help me?" It's very special and unique what we 
have created. I'm not saying it's all easy, that there hasn't been discord, but generally speaking, we know and respect each other, we read and reference each other's work. We build on each other's work, and we push things forward. I know I couldn't do the work I do without that community, not just what I read, but also that support. In the early years, when I just thought, "What am I doing?" it was people saying "what you're doing is important" and "we have got to keep doing this" that kept me doing it. I think particularly for junior faculty and graduate students, it's really important to have this community because it gives our work legitimacy and visibility.

I remember in the early years I used to get requests from graduate students: "Could you write a letter to my supervisor, my Dean, saying that motherhood studies is a discipline?" I sent letters off maybe half a dozen to a dozen times that proved to the supervisor or committee that motherhood studies existed. I'm not getting those letters anymore. I think a student could go to their department and say "I want to do mothering in, you know, science fiction, or I want to do mothering in advertising." Nobody's going to say "but is there literature on that? Is there a scholarship? Are there conferences?" because we know that there are. This has happened in less than twenty years.

M.C.M.: I expect you have an idea of the great accomplishment you have achieved and the impact of your work on academics.

Andrea: It was not only me. I threw it out in the universe, and a lot of people caught it, and carried it. I remain astonished how much this topic means to so many people who are willing to do the work, take risks and be so passionate about it. I am beyond thrilled that motherhood research is now everywhere. With this pandemic even conservtive economists are picking this up and using our words and studies. They suddenly are realizing "Oh, dear, somebody needs to do all that work we just assumed got done." I think this is a huge opportunity to harness and move us forward. To do this, I believe, we must have a feminism for mothers, what I have termed matricentric feminism. A feminism that makes motherhood the business of feminism by positioning mothers' needs and concerns as the starting point for a theory and politics on and for women's empowerment.

E.S.M.: Thank you very much for this interview. 